University of New Mexico UNM Digital Repository

6-1-2006

\title{
Why Intensive Agriculturalists Have Higher Fertility: A Household Energy Budget Approach
}

James L. Boone

Karen L. Kramer

Follow this and additional works at: https://digitalrepository.unm.edu/anth_fsp

\section{Recommended Citation}

Current Anthropology, Vol. 43, No. 3 (June 2002), pp. 511-517

This Technical Report is brought to you for free and open access by the Anthropology at UNM Digital Repository. It has been accepted for inclusion in Anthropology Faculty \& Staff Publications by an authorized administrator of UNM Digital Repository. For more information, please contact disc@unm.edu. 
Why Intensive Agriculturalists Have Higher Fertility: A Household Energy Budget Approach Author(s): Karen L. Kramer and James L. Boone

Source: Current Anthropology, Vol. 43, No. 3 (June 2002), pp. 511-517

Published by: The University of Chicago Press on behalf of Wenner-Gren Foundation for Anthropological

Research

Stable URL: http://www.jstor.org/stable/10.1086/340239

Accessed: 23/08/2011 11:02

Your use of the JSTOR archive indicates your acceptance of the Terms \& Conditions of Use, available at http://www.jstor.org/page/info/about/policies/terms.jsp

JSTOR is a not-for-profit service that helps scholars, researchers, and students discover, use, and build upon a wide range of content in a trusted digital archive. We use information technology and tools to increase productivity and facilitate new forms of scholarship. For more information about JSTOR, please contact support@jstor.org. 


\section{Reports}

\section{Why Intensive Agriculturalists Have Higher Fertility: A Household Energy Budget Approach $^{1}$}

KAREN L. KRAMER AND JAMES L. BOONE Department of Anthropology, State University of New York at Stony Brook, N.Y. I I794-4364, U.S.A. (karen.kramer@sunysb.edu)/Department of Anthropology, University of New Mexico, Albuquerque, N.M.87I3I, U.S.A. (jboone@unm.edu). 2 I VIII OI

It is widely held that human population growth rates began to increase markedly after the Pleistocene/Holocene transition largely as a consequence of the adoption of agriculture and sedentism. A common explanation for this increase in growth rates has been that circumstances associated with food production and/or the accompanying decrease in mobility allowed for higher fertility rates, but over the past decade a number of empirical studies and simulation analyses have revealed that the relationship between mode of subsistence and fertility is more complex than had previously been realized.

In I 988, Campbell and Wood published a cross-cultural compilation of total fertility rates (TFR) of 70 forager, horticultural, and intensive agricultural societies from the contemporary ethnographic record that showed no significant differences in TFRs across subsistence regimes. Hewlett (I99I) published a similar analysis of 40 mobile and sedentary foragers and pastoralists that indicated slightly higher fertility rates among pastoralists, although the difference was not significant. In I993, Bentley et al. published an extensive critique and reanalysis of the Campbell and Wood study, presenting a new cross-cultural comparison of 57 forager, horticultural, and intensive agricultural groups (Bentley, Jasien-

(C) 2002 by The Wenner-Gren Foundation for Anthropological Research. All rights reserved oOI I-3204/2002/4303-0006\$I.00

I. We are grateful to the Maya for their generosity in allowing us to live among them as part of their community. Valuable input was provided by Jane Lancaster, Hillard Kaplan, and Ronald Lee. Additionally we wish to thank Christopher Dore. This research was supported by grants from the National Science Foundation, the Tinker-Melon Foundation, the University of New Mexico, and Micro Technology. [Supplementary material appears in the electronic edition of this issue on the journal's web page (http://www.journals. uchicago.edu/CA/home.html).] ska, and Goldberg I993, Bentley, Goldberg, and Jasienska I993). Using a subset of the Campbell and Wood sample, excluding nonindependent cases (ethnic groups that were closely related) and populations with high levels of sterility, they found that intensive agriculturalists had significantly higher fertility rates (table I). Interestingly, however, horticulturalists showed slightly lower fertility than foragers in the sample, although the difference was not significant. Using a similar kind of data base, Sellen and Mace (I 997) have shown that for every Io\% increase in dependence on agriculture there is a 0.4 increase in TFR.

If sedentism or the availability of agricultural foods is indeed a decisive factor affecting TFRs across subsistence regimes, we would expect horticulture to be a clear landmark in fertility increase. That none of these studies found it so suggests that the development of agriculture or sedentism per se does not account for the increase in fertility. Yet further explanation is needed if intensive agriculturalists have a significantly higher mean TFR and are the only groups represented in the upper range of the family-size continuum. This paper explores the idea that children's contribution to underwriting the cost of large families may be an important factor conditioning variation in family size and the higher fertility attained by at least some intensive agriculturalists.

\section{A HOUSEHOLD ENERGY BUDGET APPROACH TO FERTILITY}

Parents have a finite time and energy budget out of which various activities associated with survival, maintenance, and reproduction must be funded. Time and energy expenditures are commonly subsumed under two categories: somatic effort, made up of the time and energy spent in survival and maintenance, and reproductive effort, made up of the time and energy expended in the production of offspring. The more time and energy must be allocated to resource acquisition and processing to sup-

TABLE I

TFRs for 57 Groups of Foragers, Horticulturalists, and Agriculturalists

\begin{tabular}{lllll}
\hline & \multicolumn{3}{c}{ TFR } \\
\cline { 2 - 3 } $\begin{array}{l}\text { Subsistence } \\
\text { Regime }\end{array}$ & Mean & S.E. & Range & $n$ \\
\hline & & & & \\
Foragers & 5.6 & .4 & $3.5-7.9$ & I 2 \\
Horticulturalists & 5.4 & .2 & $3.0-6.9$ & I 4 \\
Agriculturalists & 6.6 & .3 & $3.5-9.9$ & 3 I \\
\hline
\end{tabular}

NOTE: Mann-Whitney $U$ test $P$ value for foragers and horticulturalists compared with agriculturalists, 0.004 . SOURCE: Bentley, Jasienska, and Goldberg (I993:779). 
port the existing household, the less time and energy are left over to reproduce and rear additional children. Therefore, we might expect that the number of children that parents can raise is limited, among other factors, by the net efficiency of the subsistence regime.

Subsistence intensification is a process by which the amount of time or energy required to produce and/or process food increases relative to net return (Boserup I965, Brookfield I972, Earle and Christenson I980, Morrison 1994, Netting I968, among others). Typically the labor cost per unit of food increases when items are added to the diet that require more time to harvest or process to render them edible and digestible or when cultivation techniques that require more ground preparation and maintenance are adopted. In either case, the predicted consequence of subsistence intensification is decreased individual labor efficiency; that is, an individual expends more energy for each calorie acquired or produced. While not all forms of agriculture may be more energetically intensive than all forms of foraging, recent empirical analyses suggest that in general labor efficiency decreases with agriculture. In an extensive cross-cultural time-allocation study of IO2 groups of foragers, horticulturalists, and agriculturalists, Sackett (I996) found that agriculturalists spend significantly more hours per day in productive work than foragers. Barlow (I997), in a different test of the net efficiency of subsistence strategies, found that return rates (calories per hour of work) are lower for cultivated maize than for foraged plant foods and further decline with intensification (field preparation, irrigation). (For other empirical studies, see Pingali and Binswanger I987.)

In a situation in which individual efficiency (labor per unit of food) declines under intensification, holding other conditions equal, it seems reasonable that parents will find it increasingly difficult to meet the consumption demands of their family and fertility will actually decrease, not increase. The fact that it does not, at least with respect to some groups of intensive agriculturalists, raises an interesting question. How can parents working at a lower individual efficiency afford to support more children than under less intensive subsistence regimes?

As children are born into a family and the number of dependents increases, parents may reach bottlenecks in the time and/or resources they have available to support their family. During labor or resource shortfalls they have a number of options for funding their growing family's consumption demands. In a wage-labor economy with financial institutions, they can save or borrow to purchase not only goods but also child care and services to meet their children's needs. In a subsistence economy, ${ }^{2}$ however, they have to rely on themselves, their older children, their own parents, or other extended-family members for help. While much research has focused on the relationship between declining fertility and the

2. By "subsistence economy" we mean one in which food and other material goods are largely produced by the household rather than purchased with wages and little or no surplus is banked for the future. increasing cost of raising modern children, comparatively little is known about how parents meet the challenge of supporting families in traditional economies.

Using ethnographic time-allocation data for a group of Maya subsistence agriculturalists, we investigate the relationship between the way in which parents support large families and household labor organization. We use the ethnographic example of the Maya not as an analogy for a past agricultural population but as a case study of household dynamics in the intergenerational transfer of labor. Particular attention is given to the role that children's work may play in subsidizing their parents' continued reproduction.

\section{THE YUCATEC MAYA CASE STUDY}

The analysis presented below is based on time-allocation data collected by the senior author during a year-long study in a Maya community in the Puuc region of the Yucatan Peninsula, Mexico. The residents of this small, remote village are subsistence maize farmers who participate minimally in wage labor and the cash economy. They live, work, and eat in nuclear families, which form the fundamental unit of production and consumption. Each household grows its own food and furnishes the labor to provision the household. Households augment their predominantly maize diet by cultivating beans, squash, peanuts, and numerous fruits and vegetables, raising a few turkeys, ducks, chickens, or pigs, and occasionally hunting deer, peccary, armadillo, and various birds. Honey is collected for sale, and small quantities of maize may be exchanged at the two village stores for limited noncultivated goods such as eggs, rice, oil, and candles. Otherwise no cash crops are grown.

In many households men may leave the village from time to time for short periods to engage in wage labor to finance the purchase of basic household items (cloth, tools, or medicine), though in $25 \%$ of the village's 52 households men never participated in wage labor. Women are not involved in wage labor or any other income-producing enterprise. Although the income from honey sales and wage labor is used to buy basic household items, the influx of market goods and services into this community was minimal at the time of this study because of the lack of transportation and distance from market towns.

Children live and work in their parents' households until they marry and begin families of their own in their late teens to early twenties. Maize production and processing involve various unskilled, repetitive tasks that require minimal strength and can be performed easily, proficiently, and safely by children. Children are capable of planting, which is done with a simple digging stick, and spend considerable time harvesting, weeding, and carrying loads of field products to the village. Domestic chores such as carrying water, feeding animals, running errands, washing, cleaning, and shelling maize provide numerous other productive roles for children.

Family-size data were generated from reproductive histories collected during a household interview by asking 
the 3 I 6 village residents to list the names, ages, and birth dates of their parents, siblings, and children, whether living or dead. Forty-two percent of the village population participated in a year-long time-allocation study. Scan sampling techniques (Altmann I974, Borgerhoff Mulder and Caro I985) were used to collect a large number of time-allocation observations relatively quickly -more than 20,000 observations on I 29 individuals ages o to 65 . These observations provide an accurate estimate and detailed profile of the proportion of time that an individual spends in domestic, field, and leisure activities (Dunbar 1976).

\section{PRODUCTION AND CONSUMPTION ACROSS THE LIFE} COURSE

A number of observations can be made from the reproductive-history data. First, families are large: mean completed family size for village mothers 46 and older is seven children (mean 7.0, s.d. 2.03). No doubt gains have been made in reducing child mortality over the past century, but there is reason to suspect that it has historically been low $^{3}$ and that the proportion of surviving children changed little through the I90os (Kramer n.d., Kramer and McMillan I999). Second, birth spacing is relatively short-the median birth interval is 2.2 years. Among mothers aged 40 and younger, for example, I00\% in the sample have at least two children younger than age ro, and $50 \%$ have four or more children younger than age Io. Third, large families are costly in terms of the amount of work that is required to support them. Figure I shows the average number of hours (hours of work summed over all household members) that a household spends daily in work directed at maintaining the household. An average household, for example, of four members consumes 20 hours of work per day. While work generally increases with household size, the increase is not monotonic both because of the effect that an economy of scale has on household production and because of differences in age composition among families of the same size. Smaller families may be composed of either younger children or older teenage children, while larger families, which show a stepped increase in median cost, are composed of both younger children, who do not produce very much, and older children, who consume a lot.

We start by asking who produces the labor to support these large families. Is the labor of mothers and fathers sufficient to fund them? If not, to what extent do children help out? To answer these questions we need to know how much family members produce in relation to how much they consume. The most straightforward measure would express both variables in the common

3. Consumption of contaminated water and the consequent risk of gastrointestinal disease is minimized in this part of Yucatan because there is no running surface water; drinking water has been collected from closed wells for at least the past century. Prior to the wells, water was collected from small basins in the limestone caprock that would have been frequently flushed out and refilled. The isolation of the community further diminishes exposure to communicable diseases.

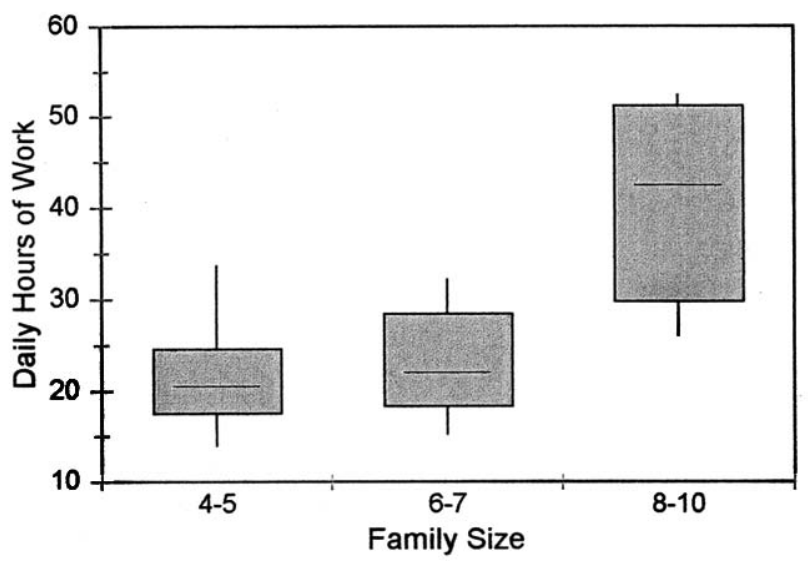

FIG. I. Estimated average daily cost of supporting families of different sizes.

currency of money or calories. However, among subsistence agriculturalists such as the Maya of this Puuc community, neither is appropriate. Monetary measures are clearly not applicable, since the agriculturalists do not cash-crop and are only nominally tied into the cash economy. Men are only intermittently employed, and women and children never engage in wage labor. Consequently, monetary earnings and expenditures would capture very little of an individual's actual production or consumption. Furthermore, in agricultural subsistence regimes a wide variety of activities that contribute to the survival and maintenance of the household, such as planting, weeding, milling, hauling water, and chopping firewood, have no calorie or cash equivalent. Yet to compare production and consumption meaningfully, we need to be able to quantify them in analogous currencies.

One way to convert subsistence activities into a common currency is to use time-the hours of work that an individual produces and consumes each day. Work includes field work (ground preparation, planting, weeding, harvesting, transporting garden goods), domestic work (washing, cleaning, sewing, food preparation, running errands, hauling water, chopping firewood, tending animals), and wage labor. ${ }^{4}$ An individual's production is expressed as the average number of daily hours spent working. Two adjustments are made to the time spent

4. Although child care was recorded in the field, it is not included in the tally of work. While direct child care activities (washing, feeding, bathing, nursing) can be clearly observed and recorded, there are many indirect forms of child care (carrying a child, talking to a child) that, depending on observer discretion, may or may not be recorded. Some mothers, for example, are naturally gregarious and talk to their children constantly. Should this be counted as care, education, or no activity at all? If child care were treated as work, personal parenting preferences would produce marked individual differences in overall work effort. Many time-allocation studies exclude child care as work for these reasons. Maya girls spend $7 \%$ of their time in child care compared with the I\% boys spend, and the inclusion of child care as work would considerably increase the time girls spend working. 
working to account for the differences in the relative value of time (e.g., Becker I98I) such that, for example, an hour spent felling trees can be compared to an hour spent swinging in a hammock.

The first value of time adjustment accounts for differences in the efficiency of children's work compared with that of adults. Relative efficiency is often estimated by return rates (amount of work produced divided by the time spent in the activity), data that were collected for a number of domestic and field activities. ${ }^{5}$ A discount coefficient is derived by dividing a child's return rate by the mean adult return rate. The discount coefficients, for example, for harvesting maize, a relatively easy task, are 0.47 for males under the age of I I, 0.7 I for males I I to I3, 0.95 for males I4 to I9, and I.O for males I9 and older. The time that a child allocates to harvesting is multiplied by the appropriate age coefficient, which in effect deflates the actual hours to a common output measure so that an hour spent by a child harvesting is comparable to an hour spent by an adult. Second, since adults and children often perform energetically different kinds of tasks, an individual's production is adjusted in such a way that time spent in more strenuous (calorically more expensive) tasks is weighted more heavily than time spent in less strenuous tasks. The scale for weighting tasks is taken from standard coefficients for taskspecific energy expenditures based on established experimental data (Durnin and Passmore 1967, National Academy of Sciences I989, Ulijaszek I995).

Individuals' consumption is estimated from the share of total household work that they consume. That share is proportional to an individual's caloric requirement based on age, sex, weight, and activity level. An individual's share is then multiplied by total household work. For example, if a household of five spends an average of 22 hours a day in work and a I2-year-old boy's share is $20 \%$ of the household's daily caloric consumption, he is estimated to consume 4.4 hours daily of household work $(22 \times .2=4.4)($ Kramer n.d.). While we cannot know for certain how household production is parceled out among family members, this method has the advantage of including an estimate of an individual's consumption of the time a household spends maintaining crops, preparing food, collecting water, washing clothes, and performing other domestic tasks.

A certain amount of labor is required to maintain a household, and household members produce varying amounts of this labor. Some individuals, most often adults, produce more than they consume, while others, particularly small children, consume more than they produce. Because consumption and the capacity for work diverge over the life course of an individual, predominantly in early childhood and perhaps in old age, in all populations some resources are reallocated from net producers to net consumers. To identify these reallocations within the household, we assume that a household's to-

5. Chopping wood, carrying water, harvesting maize, planting maize, weeding, shelling maize, grinding maize, and making tortillas. tal production and consumption balance in the long run. This means that whereas an individual household member may be a net producer or a net consumer and the amount that a household produces or consumes may change over the family life cycle, the household as a whole is not a net producer or consumer. This balancing assumption is reasonable in that the Maya of this Puuc community live in self-supporting nuclear-family households $^{6}$ that typically produce what they consume, consume what they produce, do not bank resources beyond subsistence needs, and do not systematically rely on help from other households.

Is the production balance of parents sufficient to sustain their families? Production and consumption estimates were computed for each individual in the sample and plotted against age (fig. 2). A spline smooth was fit to the individual production and consumption data points to chart the average level of production and consumption over the life course. The distance between the production and consumption curves gives the age-specific production balance-either a positive value in the case of net producers or a negative value in the case of net consumers. These curves are used first to estimate parents' production balance, or the amount of surplus time-time in excess of what is needed to support themselves-that parents have available to support other family members, notably their younger dependent children, who are net consumers. Although figure 2 indicates that parents have an average production balance of approximately three hours a day, this "surplus" time only partially compensates for their children's needs. The amount of labor needed to support the family above and beyond the time that parents have available was caluclated by subtracting parents' production balance from total household consumption (fig. 3). For every household in the sample, more hours of labor per day than parents alone are able to provide are needed to support the family. In other words, regardless of family size, parents' work effort alone does not meet the family's combined labor requirements. By all accounts Maya parents should be in a bind. Nonetheless they raise large, healthy families.

Are children helping out? The age at net production is a useful comparative measure of children's economic contribution because it distinguishes between the agerange of children dependent on others and the age-range of children who produce a surplus. We can refer to figure 3 to estimate the age at which these Maya children begin to work more than they consume and start to pay for themselves - the point at which the production function crosses and rises above the consumption function. Girls achieve net production at about age $\mathrm{I} 2$ and boys at about age 17 . Since the average age of marriage in this population is I9 $(n=50)$ for females and $22(n=43)$ for males, children of both sexes reach net production sev-

6. In the event that a particular household is a net consumer and systematically depends on labor transfers from nonmembers, then the production of its members may be overrepresented using this method. 


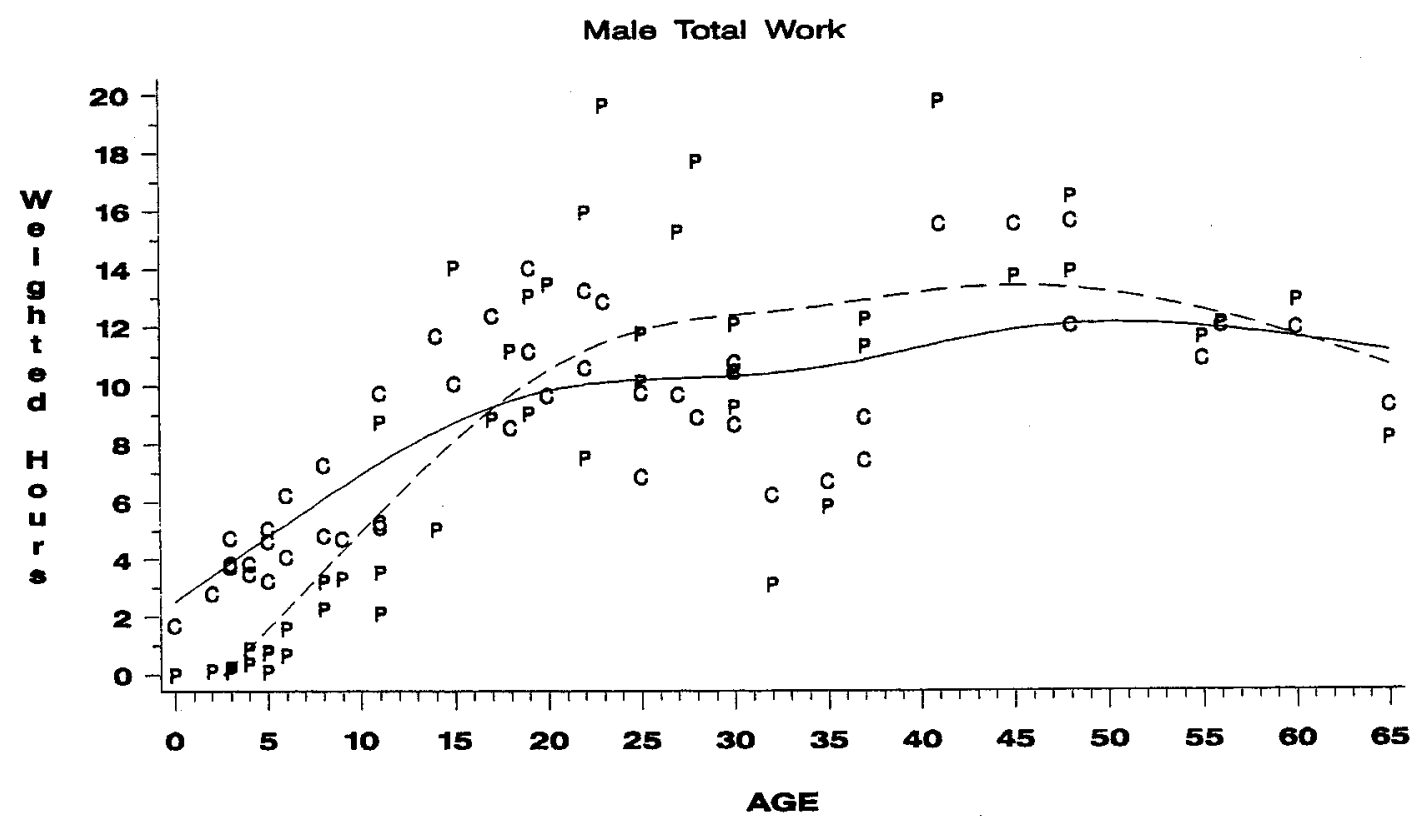

Female Total Work

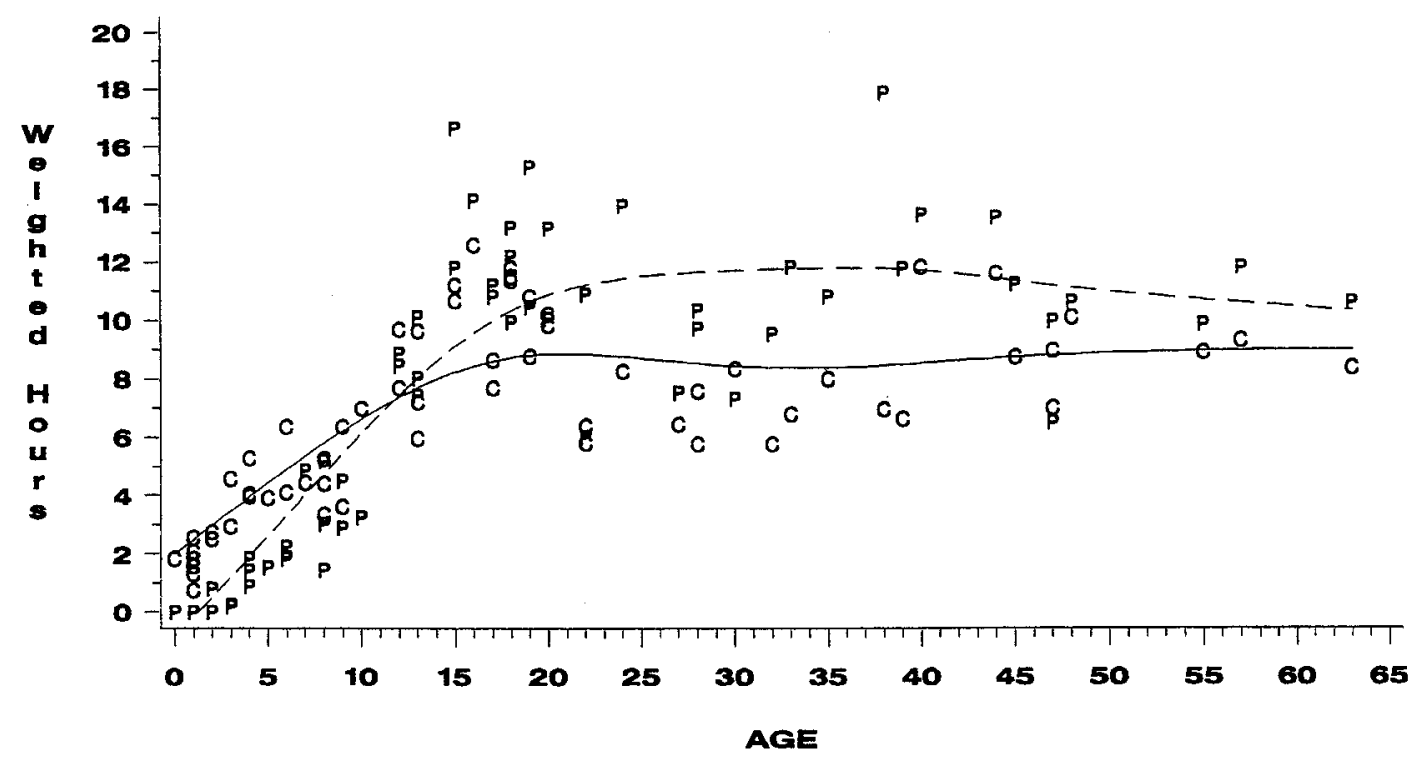

Fig. 2. Production (dotted line) and consumption (solid line) across the life course for males and females. Production and consumption are measured in weighted hours per day. $\mathrm{P}$, individual production values; $\mathrm{C}$, individual consumption values.

eral years before they leave home and begin to raise families of their own.

The literature on children's work has contributed substantially to our understanding of children's economic contributions, but there are few comparative data for net value among agriculturalists. A number of anthropological and economic studies have found that children work hard and contribute substantially to household production in agricultural economies (Munroe, Munroe, and Shimmin I984, Nag, White, and Peet I978, Minge-Kalman I978, Reynolds I99I, Vlassoff I979, among others), but few report children's consumption in relation to production. Those that do tend to be case studies of agriculturalists much more involved in wage labor than 




Fig. 3. Residual family labor deficit for families of different sizes, estimated as total household production minus the production balance of mothers and fathers.

these Maya and include only monetary earnings and expenditures (Mueller 1976, Stecklov 1999), thus underestimating many of the productive tasks in which especially young children participate. Cain (I977), in his classic study of net production, reports a younger age of net production for males (age I2), which in part may be due to his calculation of consumption including food consumption only. Further, many studies use aggregate data rather than age-specific estimates for production and consumption. Because how much children work (production) and their net value (production minus consumption) are not the same measure of children's economic value and only by using net value can we say something about the economic rationality of fertility rates, we limit our comparison to groups for which both production and consumption data are available.

The age patterning of Maya children's production and consumption contrasts markedly with that for several groups of hunter/gatherers and horticulturalists. Kaplan's (I994, I996, I997) analysis of the relationship between production and consumption for three groups of foragers and horticulturalists (Machiguenga, Piro, and Ache) found that in all three groups children provided only $20 \%$ to $25 \%$ of the calories that they consumed before the age of 18 . Children in these groups did not become net producers until their early 20 , after they already had children of their own. In these foraging and horticulturalist groups, children remain net consumers throughout their entire period of growth and development and are parents themselves when they become net producers. Maya children in contrast achieve net production five to seven years before they leave home and begin families of their own.

When we consider household production across the life cycle of the family, children as a group produce more than half of what they as a group consume after the tenth year of a marriage union, when the mother is in her prime reproductive years. Children as a group produce virtually all of what they consume after the twenty-second year of the marriage union, indicating that the economic contributions of these Maya children clearly offset a substantial portion of their consumption (Lee and Kramer 200I).

DO MAYA CHILDREN FUND FAMILY WEALTH OR UNDERWRITE THE COST OF A LARGE FAMILY?

Although empirical studies with few exceptions concur that agricultural children work hard, there is much less consensus on the end to which their labor is directed. A common view is that children's production balance is transferred to parents to improve the economic status of the family. If wealth increases as a function of the number of children, the wealth-flows hypothesis predicts that the desire for children will also increase (Caldwell I982). The idea that a large family is an economic asset has a lengthy intellectual history, but it has rarely been tested with quantitative data and our data seem to point to the contrary. Rather than improving the economic status of the family per se, these Maya children's surplus production appears rather to underwrite the cost of young dependent siblings. If these children's work funds parents' continued reproduction rather than wealth per se, this may help to explain how subsistence intensification can have a positive effect on fertility.

If the span of time between children's becoming net producers and their leaving home is variable across populations, that variation is of interest to a discussion of family size because of its effect on the competing demands on parents who must provide care to younger children and food, resources, and other services to older children - a trade-off that constrains the number of children they can raise. Any contribution that children make reduces the amount of subsidy that someone else has to make and helps to underwrite their cost. Not only do younger children help to defray their own costs, but mothers are still of reproductive age when their oldest children reach adolescence and become net producers. When dependency ratios rise and parents reach bottlenecks in their ability to support their dependents, help from children is one option available to parents to redistribute their dependent children's consumption needs. Through labor transfers children appear to play a key role in subsidizing parents' continued reproduction and allowing parents to raise more children than they might otherwise be able to support.

\section{References Cited}

ALT MANN, JEANNE. I974. Observational study of behavior: Sampling methods. Behaviour 49:227-67.

B A RL O W, K. R. I997. Foragers that farm: A behavioral ecology approach to the economics of corn farming for the Fremont case. Ph.D. diss., University of Utah, Salt Lake City, Utah.

BECKER, G. S. I98I. A treatise on the family. Cambridge: Harvard University Press. 
BENTLEY, GILLIAN, T. GOLDBERG, AND G. JASIENSKA. I993. The fertility of agricultural and non-agricultural societies. Population Studies 47:269-8I.

BENTLEY, GILLIAN, G. JASIENSKA, AND T. GOLDBERG. I993. Is the fertility of agriculturalists higher than that of nonagriculturalists? CURRENT ANTHROPOLOGY 34:778-85.

BORGERHOFF MULDER, MONIQUE, AND T. M. CARO. I985. The use of quantitative observational techniques in anthropology. CURRENT ANTHROPOLOGY 26:323-35.

B O S ERUP, ES TER. I965. The conditions of agricultural growth: The economics of agrarian change under population pressure. Chicago: Aldine.

B ROOKFIELD , H. C. I972. Intensification and disintensification in Pacific agriculture. Pacific Viewpoint I 3:2 I I-38.

CAIN, MEAD. I977. The economic activities of children in a village in Bangladesh. Population and Development Review 3: $20 \mathrm{I}-27$.

C A L D WELL, J. C. I982. Theory of fertility decline. New York: Academic Press.

CAMPBELL, K. L., AND J. W. W OOD. I988. "Fertility in traditional societies: Social and biological determinants," in Natural human fertility. Edited by P. Diggory, S. Teper, and M. Potts, pp. 39-69. London: Macmillan.

DUNBAR, R. I. M. I976. Some aspects of research design and their implication in the observation of behaviour. Behaviour $58(\mathrm{I}-2): 58-78$.

DURNIN, J. V., AND R. PASSMORE. I967. Energy, work, and leisure. London: Heinemann Educational Books.

EARLE, TIMOTHY K., AND ANDREW L. CHRISTENSON. Editors. I980. Modeling change in prehistoric subsistence economies. New York: Academic Press.

HEWLETT, BARRY S. I99I. Demography and childcare in preindustrial societies. Journal of Anthropological Research 47: I-39.

K A P L A N, H I L L A R D. I 994. Evolutionary and wealth flows theories of fertility: Empirical tests and new models. Population and Development Review 20:753-9I.

. I996. A theory of fertility and parental investment in traditional and modern human societies. Yearbook of Physical Anthropology 39:9I-I35.

. I997. "The evolution of the human life course," in Between Zeus and the salmon: The biodemography of longevity. Edited by Kenneth W. Wackter and Caleb E. Finch, pp. I75-2 I I. Washington, D.C.: National Academy of Sciences.

K RA MER, KAREN L. n.d. The children of Xculoc: Subsistence ecology, juvenile dependence, and family size in a rural Maya village. Cambridge: Harvard University Press.

KRAMER, KAREN L., AND GARNETT P. MC MILLAN. I 999. Women's labor, fertility, and the introduction of modern tech- nology in a rural Maya village. Journal of Anthropological Research 55:499-520.

LeE, RONALD D., AND KAREN L. KRAMer. 200I. Demographic influences on resource allocation in Maya households. Paper presented at the 200I annual meeting of the Population Association of America, Washington, D.C.

M I N GE-K A L M A N, W A N D A. I 978 . Household economy during the peasant-to-worker transition in the Swiss Alps. Ethnology I7:I $83-96$.

MORRIS ON, KATHLEEN. I994. The intensification of production: Archaeological approaches. Journal of Archaeological Method and Theory I:I I I-59.

MUELLER, EVA. I976. "The economic value of children in peasant agriculture," in Population and development: The search for selective interventions. Edited by Ronald Ridker, pp. 98-I 53. Baltimore: Johns Hopkins Press.

MUNROE, R. H., R. L. MUNROE, AND H. S. SHIMMIN. I984. Children's work in four cultures: Determinants and consequences. American Anthropologist 86:39-79.

NAG, M., B. WHITE, AND R. PEET. 1978. An anthropological approach to the study of the economic value of children in Java and Nepal. CURRENT ANTHROPOLOGY I9:293-306.

NATIONAL ACADEMY OF SCIENCES. Editors. I989. Recommended dietary allowances, Ioth edition. Washington, D.C.: National Academy Press.

N E T T I G G, R. M. I968. Hill farmers of Nigeria: Cultural ecology of the Kofyar of the Jos Plateau. Seattle: University of Washington Press.

PINGALI, PRABHU, AND HANS BINSWANGER. I987. "Population density and agricultural intensification: A study of the evolution of technologies in tropical agriculture," in Population growth and economic development: Issues and evidence. Edited by D. Gale Johnson and Ronald D. Lee, pp. 27-56. Madison: University of Wisconsin Press.

REY N OLDS, PA MELA. I99I. Dance civet cat: Child labour in the Zambezi Valley. Athens: Ohio University Press.

SACKETT, ROS S DE FOREST. I996. Time, energy, and the indolent savage: A quantitative cross-cultural test of the primitive affluence hypothesis. Ph.D. diss., University of California, Los Angeles, Calif.

SELLEN, D. W., AND R. MACE. I997. Fertility and mode of subsistence: A phylogenetic analysis. CURRENT ANTHROPOLOGY $38: 878-89$.

STE CKLOV, GUY. I999. Evaluating the economic returns to childbearing in Côte d'Ivoire. Population Studies 54:I-I7.

ULIJASZEK, STANLEY. I995. Human energetics in biological anthropology. Cambridge: Cambridge University Press.

VLA S S OFF, M. I979. Labour demand and economic utility of children: A case study in rural India. Population Studies 33:4I 5-28. 